\title{
Why bother with values in Higher Education?
}

\author{
Eva Egron-Polak ${ }^{1}$ \\ Former Secretary General, International Association of Universities, Council Member, Magna Charta Observatory
}

In many parts of the world, the discussion about values that underpin higher education and are important to institution of higher education, is becoming more and more frequent. Though relatively little empirical research has been done on the reasons for this resurgence of interest in values and principles, it is this author's opinion that a number of societal challenges, increased number of moral dilemmas brought about by technological capacities, as well as, at times, a questioning of university relevance, are among the reasons for university leaders, faculty and students (sometimes together and sometimes separately) to call for a renewed reflection about the values that drive higher education and for values to be better embedded in university actions.

In addition, a higher level of international interconnectedness in all spheres of life and not least in higher education, has brought about a growing cultural, ethnic and socio-economic diversity within the academic community. This too leads to comparisons and at times confrontations between value systems of different groups of people, thus nurturing the discussion about what values are proper to or relevant at any particular institution.

Under certain circumstances, very specific occurrences or developments, a crisis or a tragic event can also lead a university to re-consider or even consider for the first time, the values it subscribes to and the values it wishes to promote and instill in its graduates.

In summary, the forces and drivers that may stimulate a discussion of higher education values are quite numerous. The ways in which they are discussed, identified and hopefully adopted and translated into actions may also differ. The following brief paper will review recent work of two specific organizations, among others, that have made the issue of values, and values-based higher education a major priority in their work. The two organizations are the International Association of Universities (IAU) and the Magna Charta Observatory (MCO), respectively.

It will briefly touch on which specific values each of these two organizations has focused its work, and describe some of the actions each has taken alone and collaboratively, to stimulate more attention to values at higher education institutions worldwide.

\section{IAU and MCO promoting fundamental values}

As a UNESCO-based, global association of universities, the IAU has promoted fundamental academic values of institutional autonomy and academic freedom from its very creation in 1950. In fact, the preamble of its Constitution, brining together universities from around the world, reads as follows:

Conscious of their high responsibility as guardians of the intellectual life; Conscious of the fundamental principles for which every university should stand, namely: the right to pursue knowledge for its own sake and to follow wherever the search for truth may lead; the tolerance of divergent opinion and freedom from political interference; Conscious of their obligation as social institutions to promote, through teaching and research, the principles of freedom and justice, of human dignity and solidarity; to develop mutually material and moral aid on an international level ${ }^{2}$.

${ }^{1}$ Endereço para correspondência: E-mail: magnacharta@unibo.it

${ }^{2}$ IAU Constitution, 1950, accessed online at: 
Similarly, the MCO, created some 40 years later in 1988 in Europe by the European University Association, addressing initially European universities, was given, as its distinct and unique purpose, to gather information, express opinions and prepare documents relating to the respect for, and protection of fundamental university values and rights. These were articulated in the Magna Charta Universitatum and, echoed quite closely those of the IAU Constitution, focusing mainly on institutional autonomy and freedom from interference in the pursuit of research and teaching.

It is essential to recognize that each of these two organizations was created in very specific moment in history. IAU was calling on universities of the world to collaborate so as to build links and bridges of collaboration to repair the damage of two World Wars and in or order to prevent the possibility of such a war happening ever again. The MCO, on the other hand, came to be just as the Berlin Wall was about to come down in Europe, calling for universities to push back on interference from authoritarian regimes and, by including East European rectors in the preparation of this document, supporting the democratic developments in European countries beyond the Wall.

Both IAU and MCO have continued to focus on these fundamental academic values and encouraging universities to do so as well. However, in both cases, while their work has intensified in the last decade, or so, it has also broadened in focus. In the case in the case of the IAU, this broadening of focus consists of linking the rights to protect fundamental academic values directly to higher education institution's responsibilities to society. The IAU Policy Statement, entitled Academic Freedom, University Autonomy and Social Responsibility, articulates these responsibilities quite unequivocally, stating, for example, "Society has entrusted to the University immense responsibilities in the common endeavour of human development, social, economic, technical and cultural advance, and in responding to major planetary problems such as the preservation of the environment and the eradication of poverty, violence and social exclusion...".".

The MCO, on the other hand, has in the recent decade or so broadened its focus geographically, reaching out wellbeyond Europe to invite universities from around the world to adhere to and sign the Magna Charta Universitatum (MCU). This outreach has been quite successful, attracting a fairly large number of university leaders to become signatories to this document. At the same time, it has raised some questions and sparked a reflection both within the $\mathrm{MCO}$ and among the signatories with regard to the relevance of this seminal text to universities outside of Europe. After all, in line with the historical context of the genesis of the document and its primary target audience, the MCU addresses "A university [as] a trustee of the European humanist tradition" "and is explicitly addressed to European rectors, leading some commentators to suggest that a new, less Euro-centric statement might be in order.

While there has been no fundamental questioning of the two cornerstone principles that act as a foundation for universities worldwide, namely institutional autonomy and academic freedom, there is a discussion about additional, and perhaps equally important values that may be relevant for higher education institutions in the $21^{\text {st }}$ century. Both organisations have held such discussions in an effort to respond to new challenges and needs in society.

\section{University values for the $21^{\text {st }}$ Century}

Recent initiatives of both the MCO and the IAU demonstrate that the 21 st century brings with it both similar and different or new challenges for higher education. New threats and moral dilemmas are coming to the fore within society, thus stimulating renewed interest in promoting and protecting the fundamental values that rule academic life, but also identifying new and equally important values to protect, if universities are to fulfill their obligations to society fully. A first such initiative, started in 2011, brought the two organizations to collaborate on the development of the IAU-MCO Guidelines for an Institutional Code of Ethics in Higher Education. ${ }^{5}$

The Preamble of these Guidelines, highlights why the two organizations felt it was important to develop the guidelines. A first rationale is that "[t]he formative and socializing role of higher education in educating ever-increasing number and often a more culturally diverse group of students". Another important reason is the far-reaching, and at times unpredictable consequences of scientific and intellectual enquiry, which place additional responsibility on the entire academic community to deepen ethical selfawareness, to act with integrity and to examine continuously the ethical underpinnings and implications of their actions in the wider community. The Preamble also argues that " $[t]$ he legitimacy, credibility, support, and autonomy

\footnotetext{
${ }^{3} \mathrm{https}$ ///www.iau-aiu.net/IMG/pdf/academic_freedom_policy_statement.pdf

${ }^{4} \mathrm{MCU}$ available in X languages here:

${ }^{5} \mathrm{https}: / /$ www.iau-aiu.net/IMG/pdf/ethics_guidelines_finaldef_08.02.13.pdf
} 
of higher education institutions rest on the quality of their activities and services related to teaching and learning, research and outreach, as well as the integrity and transparency of their procedures."

Thus, ethics and values of integrity and transparency are directly linked to the demands for autonomy by universities, while the increasing number and diversity of students are underlined as reasons for higher education institutions to act as models of ethical conduct and engage in reflections about the values that are being promoted.

The preparation of these Guidelines by the two international organizations, which both have a long-standing commitment to promoting values in higher education was also a means to address and offer tools to the institutions of higher education more directly. Though the policy documents that each has elaborated and disseminated broadly in the past, as mentioned above, have been widely used and cited to promote values and principles in higher education, their normative nature has not been conducive to specific, concrete and visible actions on the part of universities. Yet, going beyond words and rhetorical statements to actions, and implementation of policies that embed the values universities believe in and promote was deemed necessary by both organization.

\section{Values under threat?}

The need to act in a more concrete and practical fashion is necessary because university values are never safe from threats. As recently as in the last two years, autonomy and academic freedom were certainly undermined in the very dramatic case of Turkey, where large numbers of university Deans and Rectors were removed from office, arrested and replaced by the government. In Hungary, the autonomy of the Central European University was seriously threatened by the government which attempted, for political reasons, to stop its right to operate in Budapest.

Technology has also brought new challenges to universities. They are facing unprecedented levels of plagiarism on the part of students, researchers, and academics at times in very senior positions, aided and facilitated by the internet. This and other kinds of scientific misconduct, such as falsifying or not sharing full results or failing to publish all methodological details of research conducted, etc., has also sparked concerns with regard to ethics and scientific integrity and led to the development of a firstever statement on scientific integrity entitled the Singapore Statement on Research Integrity ${ }^{6}$, published in 2010.
More generally, society around the globe is challenged by an increased polarization of views with regard to many issues, including immigration, multiculturalism, acceptance of diversity, increased levels of corruption among the political elites, religious intolerance and fundamentalism, etc. How a society deals and responds to these issues reflects the dominant value system and beliefs and the conflicts that arise stem whenever some group or individual challenges the prevailing set of values. Universities, cannot stand aloof from these debates and as the institutions which prepare many of the political as well as economic and social leaders, they need to increase the attention they pay to the values they instill in their graduates and the ways in which they can help identify shared values that can bring communities together rather than tearing them apart.

However, there is often a great deal of distance between the rhetorical adherence to a set of values as enshrined in political statements and the concrete policies and actions that integrate these values fully, ensuring that individuals and groups abide by them. Making sure that values and principles become a way of life rather than simply pious words, takes a different approach. The Joint Guidelines for a Code of Ethics for Higher Education Institutions, mentioned above, were deemed to be an instrument to raise awareness and help institutions review their practices to ensure that they did, in fact, operate, at every level, according to the values of academic freedom, integrity and promoted ethical conduct. The Magna Charta Observatory project entitled "Living Values", is another, more recent attempt to both learn about institutional ways of putting into action the values they cherish and helping them to make these values a way of life in the institution.

\section{Living Values project}

Each institution takes a different approach to preparing for signing up to the Magna Charta Universitatum. Often, it is a lengthy process of discussion to ensure that the values enshrined in this document are present and well-understood. The application process is designed to stimulate just such a reflection. However, once the decision is taken to become a Signatory, once the application is accepted and once the Rector has traveled to take part in the signing ceremony, does the process end there? And what happens when that Rector, who may have been the catalyst for adhering to the Universitatum, ends his or her term of tenure? Will the new leadership have the same commitment to these values? How

${ }^{6}$ https://wcrif.org/2010-singapore-statement 
is the community made aware of the fact that this commitment needs to be an enduring one? What actions are taken to ensure that signing the MCU is translated into actions? These are the key questions that led the MCO to elaborate the Living Values project.

The project has several goals - raising awareness about the MCO and the Universitatum, learning how, in various institutions, values are embedded in policy, actions and the general atmosphere, getting a sense of how values are debated within institutions and which values are deemed as most important and relevant in different contexts, are among the most important ones.

The project is in its pilot phase, with a dozen universities, in as many countries, having been invited by the MCO to take part in testing the approach and provide the Observatory with feedback in order to find the best ways to mobilize other institutions. It is too early to say how well it will achieve the various goals of the MCO and of the institutions that agreed to engage in the project. Each university had its own rationale for taking part and they will all have an opportunity to come together to share their experiences. Each institution also had an external 'MCO Ambassador' who travelled to the institution and participated in some of the activities linked to launching or carrying out the pilot project on site. The Ambassadors explained the rationale for the initiative and served as a neutral but interested observer and guide. UNICAMP, Brazil was the only institution that was selected and agreed to take part in the pilot in Latin America.

Though each pilot university adopted the approach that best suited it, for the most part, the Rector delegated the responsibility for the project to a small but representative group. In many of the pilots, including at UNICAMP these smaller coordinating groups mobilized an institutionwide consultation to learn more about their colleagues' and if possible the students' and other stakeholders' views concerning the values that were important and actively present at their university. In almost all cases, there was a need for a conceptual reflection on the meaning of some of the values, including autonomy and academic freedom but also values such as equity, integrity and others that are often taken for granted.
The exercise is still ongoing so it is impossible to draw conclusions, yet some of the expected benefits and results have already become visible to the various Ambassadors. For example, in many institutions, an initial negative reaction to the pilot on the part of the academic community whose members viewed it as simply one more administrative review and task among many, those who got involved found it a highly satisfactory 'time-out' to reflect on some fundamentals. Other benefits include the recognition that debating and agreeing on a set of values can create a sense of belonging to a community. In terms of decision-making, at all levels within the institution, being able to test a specific action against the agreed-upon values can facilitate justifying and explaining specific decisions. As well, agreeing on the values that define the institution can serve to distinguish its mission to the wider society and to potential students.

\section{Conclusion}

Higher education in the era of globalization has become a very competitive sector where each institution is competing for resources and vying for the best faculty members and the strongest students. Reputation and results are of utmost importance and in this 'race' for prestige and success, academic values and principles such as equity, integrity, protection of autonomy and academic freedom can get lost or pushed to the background. Yet, it is precisely at this time that these fundamental values are needed in order for higher education to serve society to the fullest and to play its role in promoting critical thinking, independent thought and the search for solutions without political interference and undue pressures from the market or various stakeholders.

This is why both the International Association of Universities and the Magna Charta Observatory continue to develop initiatives that highlight the importance of values and values-based higher education worldwide and encourage universities to be proactive in fully integrating values in teaching and learning, research, outreach and in the overall operational management. It is their hope that the tools they develop - such as the Guidelines for Codes of Ethics and the Living Values project - can be helpful in this endeavor.

Recebido 26/07/2018

Aceite Final 31/07/2018

Sobre a autora

Eva Egron-Polak é formada na República Tcheca, Canadá e França em Literatura Francesa, Ciência Política e Economia Política Internacional. Secretária Geral da International Association of Universities (IAU), Paris, França. Membro de comitês como UNESCO e OECD, e do Conselho da Universidade Mykolas Romeris na Lituânia e de órgãos consultivos internacionais na Holanda, Irlanda e Romênia. Coautora do $3^{\circ}$ Relatório Global de Pesquisa sobre Internacionalização do Ensino Superior em 2010. 